\title{
Article \\ Quassinoids from the Roots of Eurycoma longifolia and Their Anti-Proliferation Activities
}

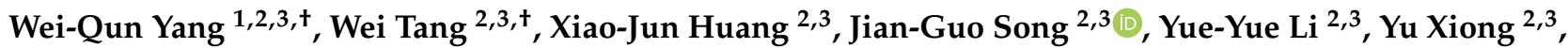 \\ Chun-Lin Fan ${ }^{2,3}$, Zhen-Long Wu ${ }^{2,3, *}$, Ying Wang ${ }^{2,3, * \mathbb{D}}$ and Wen-Cai Ye ${ }^{2,3}$
}

1 School of Pharmaceutical Sciences, Guangzhou University of Chinese Medicine, Guangzhou 510006, China; yangwq_zzy@gzucm.edu.cn

2 Center for Bioactive Natural Molecules and Innovative Drugs Research, College of Pharmacy, Jinan University, Guangzhou 510632, China; tangv163@163.com (W.T.); zhyxiaohuang@163.com (X.-J.H.); songjianguof403@126.com (J.-G.S.); liyueyue7991@163.com (Y.-Y.L.); xyu0218@163.com (Y.X.); jnuchunlin@163.com (C.-L.F.); chywc@aliyun.com (W.-C.Y.)

3 Guangdong Province Key Laboratory of Pharmacodynamic Constituents of TCM and New Drugs Research, College of Pharmacy, Jinan University, Guangzhou 510632, China

* Correspondence: zhenlongwu@jnu.edu.cn (Z.-L.W.); wangying_cpu@163.com (Y.W.); Tel.: +86-20-8522-1559 (Y.W.)

+ These authors contributed equally to this work.

Citation: Yang, W.-Q.; Tang, W.; Huang, X.-J.; Song, J.-G.; Li, Y.-Y.; Xiong, Y.; Fan, C.-L.; Wu, Z.-L.; Wang, Y.; Ye, W.-C. Quassinoids from the Roots of Eurycoma longifolia and Their Anti-Proliferation Activities. Molecules 2021, 26, 5939. https:// doi.org/10.3390/molecules26195939

Academic Editor: Valeria Costantino

Received: 30 August 2021

Accepted: 27 September 2021

Published: 30 September 2021

Publisher's Note: MDPI stays neutral with regard to jurisdictional claims in published maps and institutional affiliations.

Copyright: (c) 2021 by the authors. Licensee MDPI, Basel, Switzerland. This article is an open access article distributed under the terms and conditions of the Creative Commons Attribution (CC BY) license (https:/ / creativecommons.org/licenses/by/ $4.0 /)$.
Abstract: A phytochemical investigation on the roots of medicinal plant Eurycoma longifolia resulted in the isolation of 10 new highly oxygenated $C_{20}$ quassinoids longifolactones G-P (1-10), along with four known ones (11-14). Their chemical structures and absolute configurations were unambiguously elucidated on the basis of comprehensive spectroscopic analysis and X-ray crystallographic data. Notably, compound $\mathbf{1}$ is a rare pentacyclic $C_{20}$ quassinoid featuring a densely functionalized 2,5-dioxatricyclo[5.2.2.0 $0^{4,8}$ ] undecane core. Compound 4 represents the first example of quassinoids containing a 14,15-epoxy functionality, and 7 features an unusual $\alpha$-oriented hydroxyl group at C-14. All isolated compounds were evaluated for their anti-proliferation activities on human leukemia cells. Among the isolates, compounds 5, 12, 13, and 14 potently inhibited the in vitro proliferation of $\mathrm{K} 562$ and HL-60 cells with $\mathrm{IC}_{50}$ values ranging from 2.90 to $8.20 \mu \mathrm{M}$.

Keywords: Eurycoma longifolia; Simaroubaceae; quassinoids; natural products; anti-proliferation activities

\section{Introduction}

Quassinoids are a class of highly oxygenated degraded triterpenoids mainly distributed in plant family Simaroubaceae [1]. Based on the number of carbon atoms involving the construction of their basic scaffolds, quassinoids are commonly categorized into six distinct groups: $\mathrm{C}_{26}, \mathrm{C}_{25}, \mathrm{C}_{22}, \mathrm{C}_{20}, \mathrm{C}_{19}$, and $\mathrm{C}_{18}$ types [2]. Quassinoids have been reported to display a wide range of biological activities, including antitumor, antimalarial, anti-inflammatory, antiviral, neuroprotective, and antifeedant activities [2,3]. Especially since the discovery of bruceantin, a $C_{20}$ quassinoid isolated from Brucea antidysenteria (Simaroubaceae) in the early 1970s that showed remarkable antileukemic activity, the antitumor activities of quassinoids have attracted extensive attention from both chemical and biological communities [4-7].

Eurycoma longifolia Jack (Simaroubaceae), commonly known as "Tongkat Ali", is a flowering shrub plant that widely distributed in Southeast Asia [8]. The roots of E. longifolia were traditionally used by local people for the treatment of malaria, dysentery, glandular swelling, persistent fever, aches, and sexual insufficiency [8]. Besides, the antitumor activities of the crude extract of E. longifolia roots were reported in 2005 [9]. Previous phytochemical investigations on the roots of E. longifolia have afforded a wide variety of chemical components, including quassinoids, canthin-6-one alkaloids, $\beta$-carboline alkaloids, 
tirucallane-type triterpenes, squalene derivatives, and biphenyl neolignans [10]. Among them, quassinoids are the most characteristic chemical constituents of this plant [11-13].

Previously, our group had reported the isolation and characterization of six novelquassinoids (longifolactones A-F) with unprecedented $C_{26}$ or $C_{20}$ scaffolds from the petroleum ether-soluble fraction of the ethanol extract of E. longifolia roots [14]. Among them, longifolactione $\mathrm{F}$ is the first example of quassinoids containing an unprecedented densely functionalized 2,5-dioxatricyclo [5.2.2. $\left.0^{4,8}\right]$ undecane ring system. In our continuing studies on searching structurally unique and biologically interesting metabolites from medicinal plants, the ethyl acetate-soluble fraction of the title plant was further investigated. As a result, longifolactones G-P (1-10), 10 new $C_{20}$ quassinoids, together with four known ones were isolated. Their structures and absolute configurations were unambiguously established by extensive spectroscopic data analysis and single-crystal $X$-ray diffraction experiment. Notably, compound $\mathbf{1}$ is the second member of the rare class of quassinoids featuring densely functionalized 2,5-dioxatricyclo[5.2.2.0 $\left.0^{4,8}\right]$ undecane core. Besides, compound 4 represents the first example of quassinoids containing a 14,15-epoxy functionality, and compound 7 features an unusual $14 \alpha-\mathrm{OH}$ substituent that makes 7 the second member of this rare class of quassinoids so far. Herein, we reported the isolation and structure elucidation of these new quassinoids. In addition, the in vitro anti-proliferation activities of all isolates on two human leukemia cell lines (K562 and HL-60 cells) were also described.

\section{Results and Discussions}

\subsection{Quassinoids Isolated from E. longifolia}

The air-dried and powdered roots of E. longifolia $(10 \mathrm{~kg})$ were extracted with $95 \%$ ethanol under room temperature for five times. The ethanol extract $(270 \mathrm{~g})$ was suspended in water and partitioned successively with petroleum ether, ethyl acetate, and $n$-butanol. The ethyl acetate-soluble fraction was investigated in present study. By performing a series of charomatographic procedures on the aforementioned fraction, 10 new $\mathrm{C}_{20}$ quassinoids (longifolactones G-P, 1-10), along with four known $\mathrm{C}_{20}$ quassinoids, chaparrolide (11) [15], 15 $\beta$-hydroxyklaineanone (12) [16], 14,15 $\beta$-dihydroxyklaineanone (13) [17], and eurycomanone (14) [18], were isolated (Figure 1).
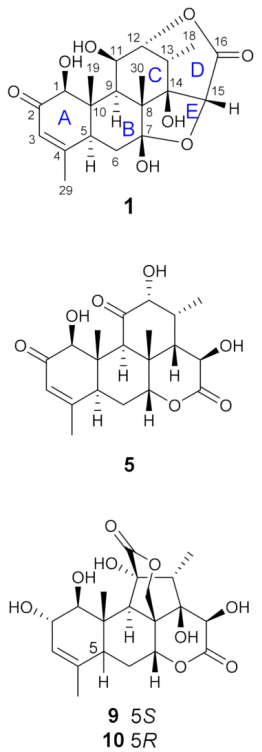
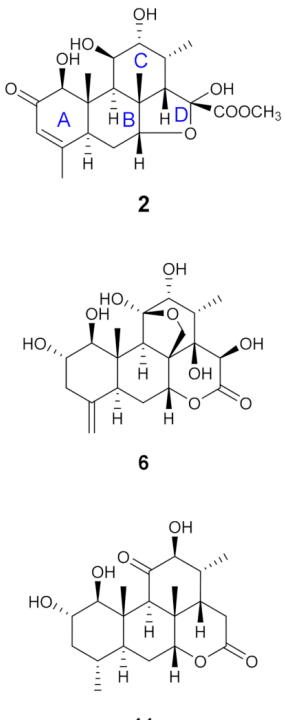

11

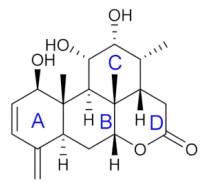

3
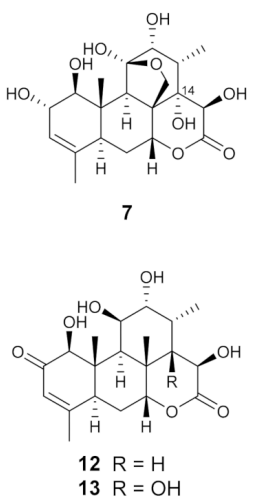

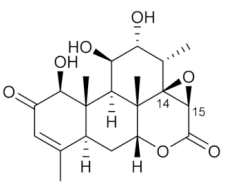

4
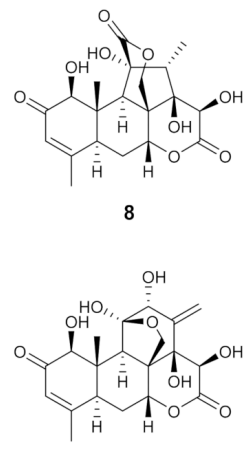

14

Figure 1. Chemical structures of quassinoids isolated from the roots of E. longifolia.

\subsection{Structure Elucidation of the New Quassinoids}

Compound 1 was obtained as colorless needles. Its molecular formula was determined as $\mathrm{C}_{20} \mathrm{H}_{26} \mathrm{O}_{8}$ by the HR-ESI-MS ion peak at $\mathrm{m} / z$ 395.1696 $[\mathrm{M}+\mathrm{H}]^{+}$(calcd for $\mathrm{C}_{20} \mathrm{H}_{27} \mathrm{O}_{8}$, 395.1700) and ${ }^{13} \mathrm{C}$ NMR data. The UV spectrum of 1 displayed absorption maxima at 
$241 \mathrm{~nm}$. Its IR spectrum revealed the characteristic absorptions for hydroxyl $\left(3455 \mathrm{~cm}^{-1}\right)$ and carbonyl (1730 and $1667 \mathrm{~cm}^{-1}$ ) functional groups. In the ${ }^{1} \mathrm{H}$ and ${ }^{13} \mathrm{C}$ NMR spectra of 1 , signals corresponding to two hydroxyl groups $\left[\delta_{\mathrm{H}} 7.05(1 \mathrm{H}, \mathrm{s})\right.$ and $6.89(1 \mathrm{H}, \mathrm{d}$, $J=5.7 \mathrm{~Hz})]$, a ketone carbonyl $\left(\delta_{\mathrm{C}} 199.7\right)$, a ester carbonyl $\left(\delta_{\mathrm{C}} 171.5\right)$, a trisubstituted double bond $\left[\delta_{\mathrm{H}} 6.07(1 \mathrm{H}, \mathrm{br} \mathrm{s}) ; \delta_{\mathrm{C}} 163.3\right.$ and 125.6], a hemiketal carbon $\left(\delta_{\mathrm{C}} 111.0\right)$, an oxygenated quaternary carbon $\left(\delta_{\mathrm{C}} 82.9\right)$, four oxygenated methines $\left[\delta_{\mathrm{H}} 5.45(1 \mathrm{H}, \mathrm{m}), 5.13(1 \mathrm{H}, \mathrm{s})\right.$, $4.72(1 \mathrm{H}, \mathrm{dd}, J=4.6,1.8 \mathrm{~Hz})$, and $4.00(1 \mathrm{H}, \mathrm{s}) ; \delta_{\mathrm{C}} 85.5,83.5,82.7$, and 69.5], three methines, a methylene, two quaternary carbons, and four methyl groups $\left[\delta_{\mathrm{H}} 1.96(3 \mathrm{H}, \mathrm{s}), 1.70(3 \mathrm{H}, \mathrm{s})\right.$, $1.39(3 \mathrm{H}, \mathrm{s})$, and $1.34(3 \mathrm{H}, \mathrm{d}, J=7.2 \mathrm{~Hz}) ; \delta_{\mathrm{C}} 21.6,13.0,12.9$, and 12.8$]$ were observed, indicative of a $C_{20}$ quassinoid skeleton for 1 . With the aid of $2 \mathrm{D}$ NMR spectroscopic data, all proton and carbon resonances of $\mathbf{1}$ were assigned (Tables S1 and S2).

The above NMR spectroscopic data of $\mathbf{1}$ were closely similar to those of longifolactone F [14], suggesting the structural similarity of these two compounds. Different from longifolactone $\mathrm{F}$, the NMR signals corresponding to a methylene group $\left(\mathrm{CH}_{2}-3\right)$ and a methine group $(\mathrm{CH}-4)$ were replaced by resonances of a double bond $\left[\delta_{\mathrm{H}} 6.07(1 \mathrm{H}, \mathrm{br} \mathrm{s}) ; \delta_{\mathrm{C}} 163.3\right.$ and 125.6] in 1. In the HMBC spectrum, key correlations between $\mathrm{H}_{3}-29$ and $\mathrm{C}-3, \mathrm{H}-5$ and $\mathrm{C}-3, \mathrm{H}_{2}-6$ and $\mathrm{C}-4$ were observed, suggesting the presence of an $\alpha, \beta$-unsaturated ketone motif in ring $\mathrm{A}$ of $\mathbf{1}$, which was also confirmed by the characteristic chemical shift values of C-2-C-4 $\left(\delta_{C} 199.7,125.6\right.$, and 163.3). After a comprehensive interpretation of its ${ }^{1} \mathrm{H}-{ }^{1} \mathrm{H}$ COSY and HMBC spectra, the gross structure of $\mathbf{1}$ was established as a $\mathrm{C}_{20}$ quassinoid with a rare 2,5-dioxatricyclo[5.2.2.0 $\left.0^{4,8}\right]$ undecane core (Figure 2).
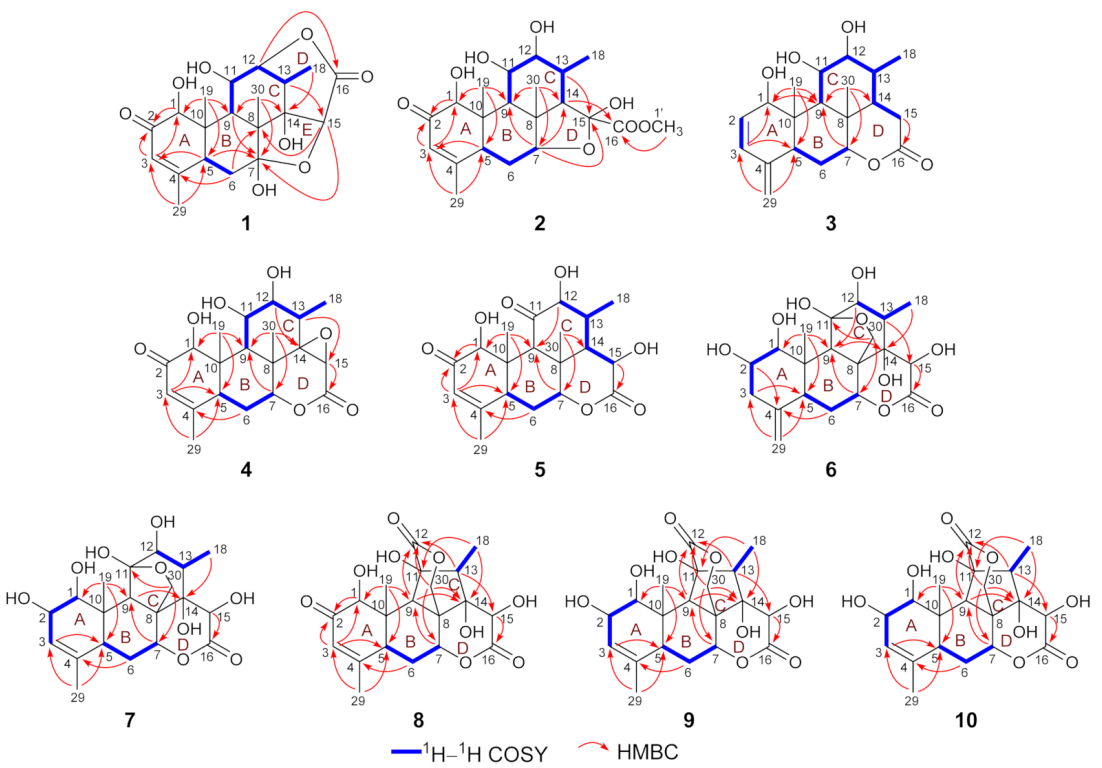

Figure 2. Key ${ }^{1} \mathrm{H}-{ }^{1} \mathrm{H}$ COSY and HMBC correlations of compounds 1-10.

In the NOESY spectrum of $\mathbf{1}$, key NOE correlations between $\mathrm{H}-1$ and $\mathrm{H}-5 / \mathrm{H}-11, \mathrm{H}-5$ and $\mathrm{H}-9$ were observed, indicating that these protons had the same orientation. Meanwhile, the NOE correlations between $\mathrm{OH}-14$ and $\mathrm{H}-15 / \mathrm{H}_{3}-30, \mathrm{H}-13$ and $\mathrm{H}_{3}-30, \mathrm{H}_{3}-19$ and $\mathrm{H}_{3}-30$ were observed, suggesting that these protons were located on the same face of the molecule (Figure 3). Finally, suitable crystals of $\mathbf{1}$ were acquired. The following X-ray diffraction analysis with $\mathrm{Cu} \mathrm{K} \alpha$ radiation resulted in an excellent Flack parameter of 0.06 (4), which not only allowed the verification of the planar structure of 1 but also led to the establishment of its absolute configuration as $1 S, 5 S, 7 R, 8 R, 9 R, 10 S, 11 R, 12 R, 13 S, 14 R, 15 R$ (Figure 4). 

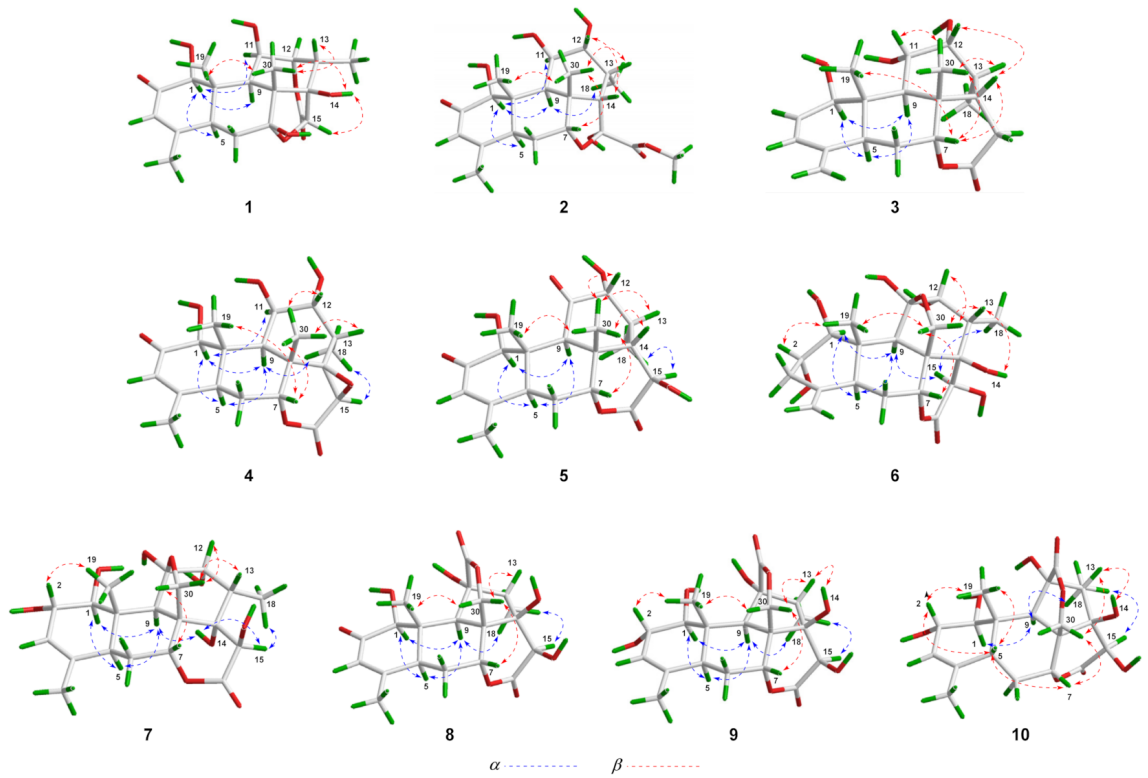

Figure 3. Key NOESY correlations of compounds 1-10.
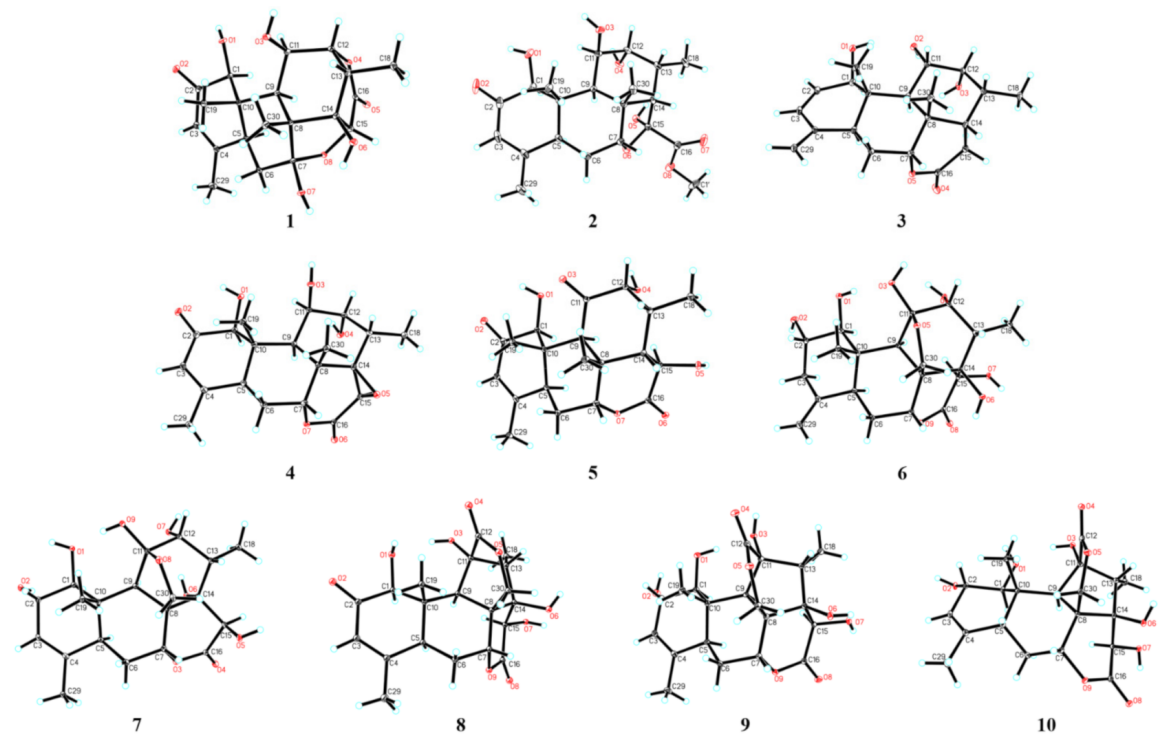

Figure 4. X-ray ORTEP drawings of compounds 1-10.

The molecular formula of 2 was deduced as $\mathrm{C}_{21} \mathrm{H}_{30} \mathrm{O}_{8}$ on the basis of its HR-ESI-MS data $\left(m / z 433.1832[\mathrm{M}+\mathrm{Na}]^{+}\right.$; calcd for $\left.\mathrm{C}_{21} \mathrm{H}_{30} \mathrm{O}_{8} \mathrm{Na}, 433.1833\right)$, and the ${ }^{13} \mathrm{C} N \mathrm{NMR}$ data analysis. The ${ }^{1} \mathrm{H}$ and ${ }^{13} \mathrm{C}$ NMR spectroscopic data of 2 (Tables S1 and S2) highly resembled those of 6-dehydroxylongilactone [19], except for the presence of additional signals due to a hemiketal carbon $\left(\delta_{\mathrm{C}} 102.5\right)$ and an oxygenated methyl group $\left[\delta_{\mathrm{H}} 3.83(3 \mathrm{H}, \mathrm{s}) ; \delta_{\mathrm{C}} 52.7\right]$ in 2. Subsequently, detailed analysis of its ${ }^{1} \mathrm{H}-{ }^{1} \mathrm{H}$ COSY and $\mathrm{HMBC}$ spectra allowed the establishment of a $6 / 6 / 6 / 5$ ring system for 2 that was identical to 6-dehydroxylongilactone. Besides, the $\mathrm{HMBC}$ correlation between $1^{\prime}-\mathrm{OCH}_{3}$ and $\mathrm{C}-16$ indicated the presence of an extra methoxycarbonyl group in 2. Based on the molecular formula information, as well as the obvious down-field shift of $\mathrm{C}-15\left(\delta_{\mathrm{C}} 102.5\right)$, the remaining methoxycarbonyl and hydroxyl groups were both assigned to attach to $C-15$, which was also confirmed by the HMBC correlation between H-14 and C-16 (Figure 2). Thus, the planar structure of 2 was established. Finally, the structure of $\mathbf{2}$ was fully resolved by an X-ray diffraction experiment. 
With an excellent Flack parameter of 0.09 (8), the absolute configuration of 2 was assigned as $1 S, 5 S, 7 R, 8 R, 9 R, 10 S, 11 R, 12 R, 13 R, 14 S, 15 S$ (Figure 4 ).

The molecular formula of 3 was determined to be $\mathrm{C}_{20} \mathrm{H}_{28} \mathrm{O}_{5}$ on the basis of its sodiated molecular ion peak at $m / z 371.1831[\mathrm{M}+\mathrm{Na}]^{+}\left(\right.$calcd for $\left.\mathrm{C}_{20} \mathrm{H}_{28} \mathrm{O}_{5} \mathrm{Na}, 371.1829\right)$ and ${ }^{13} \mathrm{C}$ NMR data. The ${ }^{1} \mathrm{H}$ and ${ }^{13} \mathrm{C}$ NMR spectral data of 3 were similar to those of the co-isolated known compound chaparrolide (11), which indicated that 3 was also a $C_{20}$ quassinoid. Compared with those of 11, the ${ }^{1} \mathrm{H}$ and ${ }^{13} \mathrm{C}$ NMR spectra of 3 showed additional signals for a cis-disubstituted double bond $\left[\delta_{\mathrm{H}} 6.31(1 \mathrm{H}, \mathrm{d}, J=9.6 \mathrm{~Hz})\right.$ and $5.76(1 \mathrm{H}, \mathrm{d}, J=9.6 \mathrm{~Hz}) ; \delta_{\mathrm{C}}$ 132.7 and 130.2] and an exo-olefin group $\left[\delta_{\mathrm{H}} 5.00(1 \mathrm{H}, \mathrm{s})\right.$ and $4.84(1 \mathrm{H}, \mathrm{s}) ; \delta_{\mathrm{C}} 145.8$ and 111.3$]$, while the signals corresponding to a ketone carbonyl, a methylene group, a methine group, and a methyl group were absent. In the ${ }^{1} \mathrm{H}-{ }^{1} \mathrm{H}$ COSY spectrum of 3 , the correlation between $\mathrm{H}-11$ and $\mathrm{H}-12$ indicated that the $\mathrm{C}-11$ in 3 was an oxygenated-substituted methine instead of the ketone carbonyl in 11 (Figure 2). Moreover, the observed HMBC cross-peaks between $\mathrm{H}_{2}-29$ and C-3/C-5, H-3 and C-5, H-3 and C- 1 indicated the presence of two conjugated double bonds in ring A of 3 (Figure 2). Similarly, an X-ray diffraction experiment using $\mathrm{Cu} \mathrm{K} \alpha$ radiation was performed, which led to the full assignment of planar structure and absolute configuration for $3(1 R, 5 S, 7 R, 8 S, 9 R, 10 S, 11 S, 12 R, 13 R, 14 S$, Figure 4$)$.

The molecular formula of 4 was assigned as $\mathrm{C}_{20} \mathrm{H}_{26} \mathrm{O}_{7}$ based on its HR-ESI-MS data $(\mathrm{m} / z \text { 401.1574 [M }+\mathrm{Na}]^{+}$; calcd for $\left.\mathrm{C}_{20} \mathrm{H}_{26} \mathrm{O}_{7} \mathrm{Na}, 401.1571\right)$ and ${ }^{13} \mathrm{C}$ NMR spectroscopic data, 18 mass units less than the co-isolated known $C_{20}$ quassinoid, 14,15 $\beta$-dihydroxyklaineanone (13). The NMR spectra of $\mathbf{4}$ showed characteristic signals similar to those of 13, except for the presence of one oxygen-bearing methine $\left[\delta_{\mathrm{H}} 3.36(1 \mathrm{H}, \mathrm{s}) ; \delta_{\mathrm{C}} 52.9\right]$ and one oxygenated bearing quaternary carbon $\left(\delta_{\mathrm{C}} 67.9\right)$. Considering the molecular formula information, the two hydroxyl groups at $\mathrm{C}-14$ and $\mathrm{C}-15$ in 13 were replaced by an epoxide ring in 4 . Furthermore, the NOE correlation between $\mathrm{H}-15$ and $\mathrm{H}_{3}-18$ in the NOESY spectrum suggested that the epoxide ring had the $\beta$-orientation (Figure 3). Similar to 1-3, the structure with absolute configuration $(1 S, 5 S, 7 R, 8 S, 9 R, 10 S, 11 R, 12 R, 13 S, 14 R, 15 R)$ of 4 was definitively assigned by an X-ray diffraction experiment (Figure 4).

The molecular formula of 5 was determined as $\mathrm{C}_{20} \mathrm{H}_{26} \mathrm{O}_{7}$ by the HR-ESI-MS ion peak at $m / z 401.1574[\mathrm{M}+\mathrm{Na}]^{+}$(calcd for $\mathrm{C}_{20} \mathrm{H}_{26} \mathrm{O}_{7} \mathrm{Na}$, 401.1571) and ${ }^{13} \mathrm{C}$ NMR data. The ${ }^{1} \mathrm{H}$ and ${ }^{13} \mathrm{C}$ NMR spectral data of 5 (Tables $\mathrm{S} 1$ and S2) were very similar to those of 11-dehydroklaineanone [20]. The main differences were that the signals corresponding to a methylene group $\left[\delta_{\mathrm{H}} 3.69(1 \mathrm{H}, \mathrm{dd}, J=19.4,12.7 \mathrm{~Hz})\right.$ and $2.70(1 \mathrm{H}, \mathrm{dd}, J=19.4,6.6 \mathrm{~Hz})$; $\left.\delta_{\mathrm{C}} 29.1\right]$ in the known compound were replaced by the signals due to an oxygenated methine $\left[\delta_{\mathrm{H}} 5.42(1 \mathrm{H}, \mathrm{d}, J=10.1 \mathrm{~Hz}) ; \delta_{\mathrm{C}} 67.3\right]$ in 5 , suggesting the presence of an additional hydroxyl group at $\mathrm{C}-15$ in 5 . This assumption was further confirmed by the HMBC crosspeak between $\mathrm{H}-15$ and C-16 (Figure 2). Subsequently, the planar structure and absolute configuration $(1 S, 5 S, 7 R, 8 S, 9 R, 10 S, 12 R, 13 R, 14 S, 15 R)$ of $\mathbf{5}$ were completely deduced by a single-crystal X-ray diffraction experiment (Figure 4).

The HR-ESI-MS of 6 displayed a sodiated molecular ion peak at $m / z 435.1626[\mathrm{M}+\mathrm{Na}]^{+}$, corresponding to a molecular formula of $\mathrm{C}_{20} \mathrm{H}_{28} \mathrm{O}_{9}$. Comparison of the ${ }^{1} \mathrm{H}$ and ${ }^{13} \mathrm{C}$ NMR spectral data of $\mathbf{6}$ (Tables S1 and S3) with those of $\Delta^{4,5}, 14$-hydroxyglaucarubol [21] revealed that they were closely similar, except for signals for the endo-olefin $\left(\delta_{\mathrm{C}} 130.1\right.$ and 127.5$)$ and a methyl $\left[\delta_{\mathrm{H}} 1.75(3 \mathrm{H}, \mathrm{s}) ; \delta_{\mathrm{C}} 20.2\right]$ in $\Delta^{4,5}, 14$-hydroxyglaucarubol were replaced by signals of an exo-olefin $\left[\delta_{\mathrm{H}} 4.98(1 \mathrm{H}, \mathrm{s})\right.$ and $4.74(1 \mathrm{H}, \mathrm{s}) ; \delta_{\mathrm{C}} 147.4$ and 110.1$]$ and a methine $\left[\delta_{\mathrm{H}} 2.74(1 \mathrm{H}\right.$, overlapped); $\left.\delta_{\mathrm{C}} 42.5\right]$ in 6 . In the HMBC spectrum, correlations between $\mathrm{H}_{2}-29$ and C-3/C-5 indicated that the exo-olefin was located at C-4 (29) (Figure 2). Thus, the planar structure of 6 was established. Similarly, the relative stereostructure and absolute configuration $(1 S, 2 S, 5 S, 7 R, 8 R, 9 R, 10 S, 11 R, 12 R, 13 S, 14 R, 15 R)$ of $\mathbf{6}$ were established by a single-crystal X-ray diffraction experiment (Figure 4).

The molecular formula of 7 was deduced as $\mathrm{C}_{20} \mathrm{H}_{28} \mathrm{O}_{9}$ by its HR-ESI-MS data $(\mathrm{m} / \mathrm{z}$ 435.1621 [M + Na $]^{+}$; calcd for $\left.\mathrm{C}_{20} \mathrm{H}_{28} \mathrm{O}_{9} \mathrm{Na}, 435.1626\right)$ and ${ }^{13} \mathrm{C}$ NMR data. The NMR spectroscopic features of 7 were similar to those of 14-epi-13,21-dihydroeurycomanone [22], except for the presence of signals assigned to an oxygenated methine $\left[\delta_{\mathrm{H}} 4.63(1 \mathrm{H}, \mathrm{br} \mathrm{s}) ; \delta_{\mathrm{C}} 72.3\right]$ 
in 7, while the signal corresponding to a ketone carbonyl carbon was absent. The above data suggested that 7 was the C-2 hydroxylated derivative of 14-epi-13,21-dihydroeurycomanone. This assumption was confirmed by the spin system deduced from $\mathrm{H}-1$ to $\mathrm{H}-3$ in the ${ }^{1} \mathrm{H}-$ ${ }^{1} \mathrm{H}$ COSY spectrum of 7 (Figure 2). Furthermore, the NOE correlation between $\mathrm{H}-2$ and $\mathrm{H}_{3}-19$ in the NOESY spectrum suggested that the $\mathrm{H}-2$ and $\mathrm{H}_{3}-19$ had the same orientation (Figure 3). Finally, with a Flack parameter of -0.12 (9), the absolute structure of $7(1 S, 2 S, 5 S, 7 R, 8 R, 9 R, 10 S, 11 R, 12 R, 13 S, 14 S, 15 R)$ was unambiguously established (Figure 4).

The HR-ESI-MS of compound 8 displayed a sodiated molecular ion peak at $\mathrm{m} / \mathrm{z} 431.1311$ $[\mathrm{M}+\mathrm{Na}]^{+}$(calcd for $\left.\mathrm{C}_{20} \mathrm{H}_{24} \mathrm{O}_{9} \mathrm{Na}, 431.1313\right)$, allowing the determination of a molecular formula of $\mathrm{C}_{20} \mathrm{H}_{24} \mathrm{O}_{9}$ that was identical to the known $\mathrm{C}_{20}$ quassinoid 13-epi-eurycomadilactone [21]. The ${ }^{1} \mathrm{H}$ and ${ }^{13} \mathrm{C}$ NMR spectral data of 8 (Tables S1 and S3) closely resembled those of 13epi-eurycomadilactone, combined with its molecular formula information, suggesting that 8 was a stereoisomer of the known compound. Further analysis of the 2D NMR data of 8 confirmed that 8 had the same planar structure as 13-epi-eurycomadilactone. Different from 13-epi-eurycomadilactone, the NOESY spectrum of 8 showed the correlation between $\mathrm{H}-13$ and $\mathrm{H}_{2}-30$, indicating the $\alpha$-orientation for the $\mathrm{H}_{3}-18$ in 8 (Figure 3). The structure with absolute configuration $(1 S, 5 S, 7 R, 8 R, 9 R, 10 S, 11 S, 13 R, 14 R, 15 R)$ of $\mathbf{8}$ was finally determined on the basis of an $\mathrm{X}$-ray crystallography study by using the anomalous dispersion of $\mathrm{Cu} \mathrm{K} \alpha$ radiation (Figure 4).

Compound 9 was assigned to possess a molecular formula of $\mathrm{C}_{20} \mathrm{H}_{26} \mathrm{O}_{9}$ by the HRESI-MS ion peak at $m / z 433.1472[\mathrm{M}+\mathrm{Na}]^{+}$(calcd for $\left.\mathrm{C}_{20} \mathrm{H}_{26} \mathrm{O}_{9} \mathrm{Na}, 433.1469\right)$ and $1 \mathrm{D}$ NMR spectral data analysis, which was two mass units more than that of 8 . The ${ }^{1} \mathrm{H}$ and ${ }^{13} \mathrm{C}$ NMR spectra of $\mathbf{9}$ exhibited similar signals to those of 8 (Tables S1 and S3), except for the signal assigned to a ketone carbonyl $\left(\delta_{\mathrm{C}} 197.0, \mathrm{C}-2\right.$ in 8$)$ was replaced by the signals of an oxygenated methine $\left[\delta_{\mathrm{H}} 4.55\left(1 \mathrm{H}\right.\right.$, overlapped); $\left.\delta_{\mathrm{C}} 72.5\right]$ in 9. Thus, compound 9 was assumed to be a C-2 hydroxylated derivative of 8 . This deduction was further verified by the spin system from $\mathrm{H}-1$ to $\mathrm{H}-3$ in the ${ }^{1} \mathrm{H}-{ }^{1} \mathrm{H}$ COSY spectrum of 9 (Figure 2). Furthermore, the $\alpha$-orientation of the 2-OH was determined on the basis of key NOE correlation between $\mathrm{H}-2$ and $\mathrm{H}_{3}-19$ (Figure 3). A further crystallographic analysis led to the unambiguous establishment of the structure and absolute configuration $(1 S, 2 S, 5 S, 7 R, 8 R, 9 R, 10 S, 11 S, 13 R, 14 R, 15 R)$ of 9 (Figure 4$)$.

The molecular formula of $\mathbf{1 0}$ was deduced to be identical to that of $\mathbf{9}$ on the basis of its HR-ESI-MS data $\left(\mathrm{m} / z 433.1470[\mathrm{M}+\mathrm{Na}]^{+}\right.$; calcd for $\left.\mathrm{C}_{20} \mathrm{H}_{26} \mathrm{O}_{9} \mathrm{Na}, 433.1469\right)$ and ${ }^{13} \mathrm{C}$ NMR data. Comparison of the NMR data of $\mathbf{1 0}$ with those of $\mathbf{9}$ (Tables S1 and S3) indicated that 10 possessed the identical gross structure to 9 . The main differences of the NMR spectral data between 10 and $\mathbf{9}$ were the obvious down-field shifts of $C-5(\Delta \delta+5.1)$ and C-6 $(\Delta \delta+5.2)$ in 10, suggesting that $\mathbf{1 0}$ might be a C-5 epimer of $\mathbf{9}$. Further analysis of its 2D NMR spectroscopic data verified that 10 possessed the identical planar structure to 9. In the NOESY spectrum, NOE correlation between $\mathrm{H}-5$ and $\mathrm{H}_{3}-19$ was observed, suggesting the $\beta$-orientation for $\mathrm{H}-5$ in $\mathbf{1 0}$ (Figure 3). Similar to $\mathbf{1 - 9}$, the single-crystal X-ray diffraction study $(\mathrm{Cu} \mathrm{K} \alpha)$ allowed the assignment of the complete stereochemistry of 10. As a result, the absolute configuration of $\mathbf{1 0}$ was definitively assigned to be $1 S, 2 S, 5 R, 7 R, 8 R, 9 R, 10 S, 11 S, 13 R, 14 R, 15 R$ (Figure 4).

\subsection{Anti-proliferation Activities of Isolated Quassinoids}

The isolated compounds were tested for their anti-proliferation activities on two human leukemia cell lines, K562 and HL-60. As shown in Table S5, compounds 5, 12, 13, and 14 exhibited potent inhibitory effects on the proliferation of both K562 and HL-60 cells with $\mathrm{IC}_{50}$ values ranging from 2.90 to $8.20 \mu \mathrm{M}$.

\section{Materials and Methods}

\subsection{General Methods}

Melting points were measured on an X-5 melting point instrument (Fukai, Beijing, China) without correction. Optical rotations were determined in $\mathrm{MeOH}$ on a P-1020 polarimeter (JASCO, Tokyo, Japan) with a $1 \mathrm{~cm}$ cell at room temperature. UV spectra 
were acquired on a JASCO V-500 UV/vis spectrometer. IR spectra were obtained with a JASCO FT/IR-480 plus infrared spectrometer using KBr pellets. HR-ESI-MS data were collected using an Agilent 6210 TOF-MS spectrometer (Agilent Technologies, Santa Clara, CA, USA). Other experimental procedures were performed as described previously [14]. The human leukemia cell lines, HL-60 and K562, were purchased from the American Type Culture Collection (ATCC) and cultured in RPMI-1640 medium supplemented with 10\% fetal bovine serum (FBS) and $2 \mathrm{mM}$ L-glutamine.

\subsection{Plant Material}

The roots of Eurycoma longifolia were collected from Malacca, Malaysia, in June 2014 and authenticated by Prof. Guang-Xiong Zhou (College of Pharmacy, Jinan University). A voucher specimen (No. 20140501) was deposited in the Center for Bioactive Natural Molecules and Innovative Drugs Research, College of Pharmacy, Jinan University.

\subsection{Extraction and Isolation}

The air-dried and powdered roots of E. longifolia $(10 \mathrm{~kg})$ were extracted with $95 \%$ $(v / v)$ EtOH five times at room temperature. The combined EtOH extract was concentrated under vacuum to yield a crude extract $(270 \mathrm{~g})$, which was suspended in water and then partitioned successively with petroleum ether, ethyl acetate, and $n-\mathrm{BuOH}$.

The ethyl acetate-soluble fraction $(95 \mathrm{~g})$ was subjected to silica gel column chromatography using gradient mixture of $\mathrm{CHCl}_{3}-\mathrm{MeOH}(100: 0 \rightarrow 0: 100, v / v)$ as eluent to afford 10 major fractions (Fr.1-Fr.10).

Fr.2 (30.5 g) was further separated on a silica gel column (petroleum ether-EtOAc, 100:0 $\rightarrow$ 0:100, $v / v)$ to give six subfractions Fr.2A-Fr.2F. Fr.2B (1.2 g) was purified by a Sephadex $\mathrm{LH}-20$ column $\left(\mathrm{CHCl}_{3}-\mathrm{MeOH}, 1: 1\right)$ followed by semipreparative $\mathrm{HPLC}\left(\mathrm{CH}_{3} \mathrm{CN}\right.$ $\left.\mathrm{H}_{2} \mathrm{O}, 35: 65, v / v\right)$ to yield compounds $2(5.0 \mathrm{mg})$ and $4(8.0 \mathrm{mg})$. Then, Fr.2D $(15.0 \mathrm{~g})$ was separated over an ODS column $\left(\mathrm{MeOH}-\mathrm{H}_{2} \mathrm{O}, 20: 80 \rightarrow 100: 0\right)$ to afford six subfractions (Fr.2D-1-Fr.2D-6). Fr.2D-2 (3.0 g) was subsequently purified by semipreparative HPLC $\left(\mathrm{MeOH}-\mathrm{H}_{2} \mathrm{O}, 30: 70, v / v\right)$ to give compounds $1(14.5 \mathrm{mg})$ and $11(8.4 \mathrm{mg})$, and Fr.2D-4 $(1.5 \mathrm{~g})$ was also purified by preparative $\mathrm{HPLC}\left(\mathrm{MeOH}-\mathrm{H}_{2} \mathrm{O}, 35: 65, v / v\right)$ to afford compound $3(6.0 \mathrm{mg})$. Fr.3 (5.0 g) was applied to a Sephadex LH-20 column $(\mathrm{MeOH})$ and gave five subfractions Fr.3A-Fr.3E. Furthermore, Fr.3B was further subjected to preparative HPLC $\left(\mathrm{MeOH}-\mathrm{H}_{2} \mathrm{O}, 32: 68, v / v\right)$ to give compound $12(45.0 \mathrm{mg})$.

Fr. $6(20.0 \mathrm{~g})$ was purified over an ODS column using $\mathrm{MeOH}-\mathrm{H}_{2} \mathrm{O}(20: 80 \rightarrow 100: 0$, $v / v)$ as eluent to afford eight subfractions (Fr.6A-Fr.6H). Fr.6B ( $8.0 \mathrm{~g})$ was subjected to a Sephadex LH-20 column (MeOH) to yield five subfractions (Fr.6B-1-Fr.6B-5). Fr.6B-2 (3.0 g) was purified by semipreparative HPLC $\left(\mathrm{CH}_{3} \mathrm{CN}-\mathrm{H}_{2} \mathrm{O}, 18: 82, v / v\right)$ to give compounds 5 (7.4 mg), 6 (10.0 mg), 7 (40.5 mg), and $13(1.5 \mathrm{~g})$, respectively. Fr.6B-4 (500 mg) was purified by preparative $\mathrm{HPLC}\left(\mathrm{CH}_{3} \mathrm{CN}-\mathrm{H}_{2} \mathrm{O}, 18: 82, v / v\right)$ to give compounds $8(25.3 \mathrm{mg})$, 9 (5.2 mg), and 10 (5.1 mg).

Fr.9 (3.5 g) was applied to a Sephadex LH-20 column (MeOH) to obtain four subfractions Fr.9A-Fr.9D. Then, Fr.9C (1.2 g) was further subjected to preparative HPLC separation $\left(\mathrm{CH}_{3} \mathrm{CN}-\mathrm{H}_{2} \mathrm{O}, 12: 88, v / v\right)$ to afford compound $14(80 \mathrm{mg})$.

\subsection{Compounds Characterization}

Longifolactone $\mathrm{G}(\mathbf{1})$ : colorless needles $(\mathrm{MeOH}) ; \mathrm{mp} 290-291{ }^{\circ} \mathrm{C} ;[\alpha]_{\mathrm{D}}^{25}+58.0(c 0.55$, $\mathrm{MeOH}) ; \mathrm{UV}\left(\mathrm{CH}_{3} \mathrm{CN}\right) \lambda_{\max }(\log \varepsilon): 241(3.81) \mathrm{nm}$; IR (KBr) $v_{\max } 3455,2957,1730,1667$, $1432,1379,1348,1229,1198,1115,1017,973,878 \mathrm{~cm}^{-1} ;{ }^{1} \mathrm{H}$ and ${ }^{13} \mathrm{C}$ NMR spectral data, see Tables S1 and S2; HR-ESI-MS $m / z 395.1696[\mathrm{M}+\mathrm{H}]^{+}$(calcd for $\mathrm{C}_{20} \mathrm{H}_{27} \mathrm{O}_{8}, 395.1700$ ).

Longifolactone $\mathrm{H}(2)$ : colorless needles $(\mathrm{MeOH}) ; \mathrm{mp} 225-226{ }^{\circ} \mathrm{C} ;[\alpha]_{\mathrm{D}}^{25}-6.2(c 0.34$, $\mathrm{MeOH}) ; \mathrm{UV}\left(\mathrm{CH}_{3} \mathrm{CN}\right) \lambda_{\max }(\log \varepsilon): 241(4.01) \mathrm{nm}$; IR (KBr) $v_{\max } 3432,2941,1725,1662$, 1380, 1262, 1122, 998, 819, $564 \mathrm{~cm}^{-1} ;{ }^{1} \mathrm{H}$ and ${ }^{13} \mathrm{C}$ NMR spectral data, see Tables S1 and S2; HR-ESI-MS $m / z 433.1832[\mathrm{M}+\mathrm{Na}]^{+}\left(\right.$calcd for $\mathrm{C}_{21} \mathrm{H}_{30} \mathrm{O}_{8} \mathrm{Na}, 433.1833$ ). 
Longifolactone I (3): colorless needles (MeOH); mp 178-179 ${ }^{\circ} \mathrm{C} ;[\alpha]_{\mathrm{D}}^{25}+56.0(c 0.46$, $\mathrm{MeOH}) ; \mathrm{UV}\left(\mathrm{CH}_{3} \mathrm{CN}\right) \lambda_{\max }(\log \varepsilon) ; 230$ (3.97) nm; IR (KBr) $v_{\max }: 3468,3346,2953,2904$, $2577,1727,1496,1411,1316,1226,1128,1057,1015,963,813,712,638 \mathrm{~cm}^{-1} ;{ }^{1} \mathrm{H}$ and ${ }^{13} \mathrm{C}$ NMR spectral data, see Tables S1 and S2; HR-ESI-MS: $m / z$ 371.1831 [M + Na] ${ }^{+}$(calcd for $\mathrm{C}_{20} \mathrm{H}_{28} \mathrm{O}_{5} \mathrm{Na}, 371.1829$ ).

Longifolactone J (4): colorless needles $(\mathrm{MeOH}) ; \mathrm{mp} 255-256^{\circ} \mathrm{C} ;[\alpha]_{\mathrm{D}}^{25}+18.2(\mathrm{c} 0.29$, $\mathrm{MeOH}) ; \mathrm{UV}\left(\mathrm{CH}_{3} \mathrm{CN}\right) \lambda_{\max }(\log \varepsilon): 241(3.75) \mathrm{nm}$; IR (KBr) $v_{\max } 3450,2943,1726,1656,1434$, $1379,1347,1261,1196,1123,1063,998,959,589,523 \mathrm{~cm}^{-1} ;{ }^{1} \mathrm{H}$ and ${ }^{13} \mathrm{C}$ NMR spectral data, see Tables S1 and S2; HR-ESI-MS $m / z$ 401.1574 [M + Na] ${ }^{+}$(calcd for $\mathrm{C}_{20} \mathrm{H}_{26} \mathrm{O}_{7} \mathrm{Na}$, 401.1571).

Longifolactone $\mathrm{K}(5)$ : colorless needles $\left(\mathrm{MeOH}-\mathrm{C}_{5} \mathrm{H}_{5} \mathrm{~N}\right) ; \mathrm{mp} 266-267^{\circ} \mathrm{C} ;[\alpha]_{\mathrm{D}}^{25}-7.2$ (c 0.31, MeOH); UV ( $\mathrm{CH}_{3} \mathrm{CN}$ ) $\lambda_{\max }(\log \varepsilon): 240(4.01) \mathrm{nm}$; IR (KBr) $\mathrm{v}_{\max } 3429,2944,1726,1660$, $1435,1381,1261,1122,1064,997,964,902,819,698,449 \mathrm{~cm}^{-1} ;{ }^{1} \mathrm{H}$ and ${ }^{13} \mathrm{C}$ NMR spectral data, see Tables S1 and S2; HR-ESI-MS m/z 401.1574 [M + Na] ${ }^{+}$(calcd for $\mathrm{C}_{20} \mathrm{H}_{26} \mathrm{O}_{7} \mathrm{Na}$, 401.1571).

Longifolactone L (6): colorless needles $(\mathrm{MeOH}) ; \mathrm{mp} 265-266^{\circ} \mathrm{C},[\alpha]_{\mathrm{D}}^{25}+22.2(c 0.92$, $\mathrm{MeOH}) ; \mathrm{UV}\left(\mathrm{CH}_{3} \mathrm{CN}\right) \lambda_{\max }(\log \varepsilon): 195$ (3.80) nm; IR (KBr) v $v_{\max }$ : 3468, 3354, 2951, 2904, 2719, $1729,1499,1389,1314,1226,1125,1055,964,814 \mathrm{~cm}^{-1} ;{ }^{1} \mathrm{H}$ and ${ }^{13} \mathrm{C}$ NMR spectral data, see Tables S1 and S3; HR-ESI-MS m/z 435.1626 [M + Na] ${ }^{+}$(calcd for $\mathrm{C}_{20} \mathrm{H}_{28} \mathrm{O}_{9} \mathrm{Na}$, 435.1626).

Longifolactone $\mathrm{M}(7)$ : colorless needles $(\mathrm{MeOH}) ; \mathrm{mp} 300-301{ }^{\circ} \mathrm{C} ;[\alpha]_{\mathrm{D}}^{25}+10.1$ (c 0.70, $\mathrm{MeOH}) ; \mathrm{UV}\left(\mathrm{CH}_{3} \mathrm{CN}\right) \lambda_{\max }(\log \varepsilon): 198(3.60) \mathrm{nm} ; \mathrm{IR}(\mathrm{KBr}) v_{\max } 3304,2886,1737,1654$, 1507, 1456, 1426, 1332, 1281, 1234, 1081, 993, $917 \mathrm{~cm}^{-1} ;{ }^{1} \mathrm{H}$ and ${ }^{13} \mathrm{C}$ NMR spectral data, see Tables S1 and S3; HR-ESI-MS m/z $435.1621[\mathrm{M}+\mathrm{Na}]^{+}$(calcd for $\mathrm{C}_{20} \mathrm{H}_{28} \mathrm{O}_{9} \mathrm{Na}, 435.1626$ ).

Longifolactone $\mathrm{N}(8)$ : colorless needles $(\mathrm{MeOH}) ; \mathrm{mp} 248-249{ }^{\circ} \mathrm{C},[\alpha]_{\mathrm{D}}^{25}+44.6(c 0.67$, $\mathrm{MeOH}) ; \mathrm{UV}\left(\mathrm{CH}_{3} \mathrm{CN}\right) \lambda_{\max }(\log \varepsilon): 240(3.46) \mathrm{nm}$; IR (KBr) $v_{\max }: 3495,3324,1739,1664$, 1491, 1394, 1252, 1155, 1108, 1066, 973, $823 \mathrm{~cm}^{-1} ;{ }^{1} \mathrm{H}$ and ${ }^{13} \mathrm{C}$ NMR spectral data, see Tables S1 and S3; HR-ESI-MS m/z 431.1311 [M + Na] ${ }^{+}$(calcd for $\mathrm{C}_{20} \mathrm{H}_{24} \mathrm{O}_{9} \mathrm{Na}, 431.1313$ ).

Longifolactone $\mathrm{O}(9)$ : colorless needles $(\mathrm{MeOH}) ; \mathrm{mp} 245-246{ }^{\circ} \mathrm{C},[\alpha]_{\mathrm{D}}^{25}+4.2($ c 3.07, $\mathrm{MeOH}) ; \mathrm{UV}\left(\mathrm{CH}_{3} \mathrm{CN}\right) \lambda_{\max }(\log \varepsilon): 198(3.63) \mathrm{nm} ; \mathrm{IR}(\mathrm{KBr}) v_{\max }: 3307,2915,1737,1659,1489$, 1434, 1389, 1192, 1156, 1104, $974 \mathrm{~cm}^{-1} ;{ }^{1} \mathrm{H}$ and ${ }^{13} \mathrm{C}$ NMR spectral data, see Tables S1 and S3; HR-ESI-MS: $m / z 433.1472[\mathrm{M}+\mathrm{Na}]^{+}$(calcd for $\mathrm{C}_{20} \mathrm{H}_{26} \mathrm{O}_{9} \mathrm{Na}, 433.1469$ ).

Longifolactone $\mathrm{P}(\mathbf{1 0})$ : colorless needles $(\mathrm{MeOH}) ; \mathrm{mp} 265-266^{\circ} \mathrm{C} ;[\alpha]_{\mathrm{D}}^{25}-1.3(c 0.15$, $\mathrm{MeOH}) ; \mathrm{UV}\left(\mathrm{CH}_{3} \mathrm{CN}\right) \lambda_{\max }(\log \varepsilon): 196(3.70) \mathrm{nm}$; IR (KBr) $v_{\max }$ : 3491, 3305, 1739, 1661, 1389, 1250, 1154, 1108, 1064, 975, $835 \mathrm{~cm}^{-1} ;{ }^{1} \mathrm{H}$ and ${ }^{13} \mathrm{C}$ NMR spectral data, see Tables S1 and S3; HR-ESI-MS $m / z 433.1470[\mathrm{M}+\mathrm{Na}]^{+}$(calcd for $\mathrm{C}_{20} \mathrm{H}_{26} \mathrm{O}_{9} \mathrm{Na}, 433.1469$ ).

Chaparrolide (11): colorless needles (MeOH); mp 184-185 ${ }^{\circ} \mathrm{C} ;[\alpha]_{\mathrm{D}}^{25}+15.6($ c $0.11, \mathrm{MeOH})$; $\mathrm{UV}\left(\mathrm{CH}_{3} \mathrm{CN}\right) \lambda_{\max }(\log \varepsilon): 196$ (3.94) nm; IR (KBr) $v_{\max } 3484,3369,2961,1720,1381,1242,1098$, 1054, 982, $810 \mathrm{~cm}^{-1} ;{ }^{1} \mathrm{H}$ and ${ }^{13} \mathrm{C}$ NMR spectral data, see Table S4 in Supplementary Materials; HR-ESI-MS $m / z 389.1940[\mathrm{M}+\mathrm{Na}]^{+}$(calcd for $\mathrm{C}_{20} \mathrm{H}_{30} \mathrm{O}_{6} \mathrm{Na}, 389.1935$ ).

$15 \beta$-Hydroxyklaineanone (12): colorless needles (MeOH); mp 223-224 ${ }^{\circ} \mathrm{C} ;[\alpha]_{\mathrm{D}}^{25}+6.3$ (c 1.73, MeOH); UV $\left(\mathrm{CH}_{3} \mathrm{CN}\right) \lambda_{\max }(\log \varepsilon): 242(4.05) \mathrm{nm}$; IR (KBr) $v_{\max } 3460,2950,1733$, $1671,1436,1378,1259,1124,1068,1000,958,902,814,697,633 \mathrm{~cm}^{-1} ;{ }^{1} \mathrm{H}$ and ${ }^{13} \mathrm{C}$ NMR spectral data, see Table S4 in Supplementary Materials; HR-ESI-MS m/z $403.1734[\mathrm{M}+\mathrm{Na}]^{+}$ (calcd for $\mathrm{C}_{20} \mathrm{H}_{28} \mathrm{O}_{7} \mathrm{Na}$, 403.1727).

14,15 $\beta$-Dihydroxyklaineanone (13): colorless needles (MeOH); mp 266-267 ${ }^{\circ} \mathrm{C} ;[\alpha]_{\mathrm{D}}^{25}$ +54.3 ( c 0.51, MeOH); $\mathrm{UV}\left(\mathrm{CH}_{3} \mathrm{CN}\right) \lambda_{\max }(\log \varepsilon): 241$ (4.05) nm; IR (KBr) $v_{\max } 3425,2945$, 1726, 1660, 1435, 1381, 1344, 1262, 1122, 1064, 998, 964, 902, 818, $698 \mathrm{~cm}^{-1} ;{ }^{1} \mathrm{H}$ and ${ }^{13} \mathrm{C}$ NMR spectral data, see Table S4 in Supplementary Materials; HR-ESI-MS m/z $419.1674[\mathrm{M}+\mathrm{Na}]^{+}$ (calcd for $\mathrm{C}_{20} \mathrm{H}_{28} \mathrm{O}_{8} \mathrm{Na}$, 419.1676).

Eurycomanone (14): colorless needles $(\mathrm{MeOH}) ; \mathrm{mp} 285-286^{\circ} \mathrm{C} ;[\alpha]_{\mathrm{D}}^{25}+39.5(c 0.65$, $\mathrm{MeOH}) ; \mathrm{UV}\left(\mathrm{CH}_{3} \mathrm{CN}\right) \lambda_{\max }(\log \varepsilon): 241(3.46) \mathrm{nm}$; IR (KBr) $v_{\max } 3402,2981,2880,1736$, $1676,1622,1504,1435,1312,1231,1121,1056,985,826,765 \mathrm{~cm}^{-1} ;{ }^{1} \mathrm{H}$ and ${ }^{13} \mathrm{C}$ NMR spectral data, see Table S4 in Supplementary Materials; HR-ESI-MS m/z $431.1314[\mathrm{M}+\mathrm{Na}]^{+}$(calcd for $\mathrm{C}_{20} \mathrm{H}_{24} \mathrm{O}_{9} \mathrm{Na}$, 431.1313). 


\subsection{X-ray Crystallographic Analyses}

The crystal data of compounds 1-10 were collected using an Oxford-Diffraction SuperNova diffractometer (Agilent Technologies, Yarnton, UK) with $\mathrm{Cu} \mathrm{K} \alpha$ radiation. The crystal structures were solved by direct methods using the SHELXS program (Sheldrick, 2019) [23], and refined by the SHELXL-2018 program (Sheldrick, 2019) [23] and full-matrix least-squares calculation. Crystal data of compounds 1-10 in standard CIF format were deposited with the Cambridge Crystallographic Data Centre (CCDC 2,105,724 for 1, CCDC 2,105,722 for 2, CCDC 2,105,723 for 3, CCDC 2,105,731 for 4, and CCDC 2,105,730 for 5, CCDC 2,105,729 for 6, CCDC 2,105,727 for 7, and CCDC 2,105,725 for 8, CCDC 2,105,726 for 9 , and CCDC 2,105,728 for 10).

Crystal data for compound $\mathbf{1}(\mathrm{M}=394.41 \mathrm{~g} / \mathrm{mol})$ : orthorhombic, space group $\mathrm{P} 2{ }_{1} 2_{1} 2_{1}$, $\mathrm{a}=7.17350(10) \AA, \mathrm{b}=10.18810(10) \AA, \mathrm{c}=24.5189(2) \AA, \beta=90^{\circ}, \mathrm{V}=1791.95(3) \AA^{3}, \mathrm{Z}=4$, $\mathrm{T}=99.99(10) \mathrm{K}, \mu(\mathrm{Cu} \mathrm{K} \alpha)=0.948 \mathrm{~mm}^{-1}, \mathrm{D}_{\text {calc }}=1.462 \mathrm{~g} / \mathrm{cm}^{3}, 21,948$ reflections measured $\left(7.21^{\circ} \leq 2 \theta \leq 147.054^{\circ}\right), 3593$ unique $\left(R_{\text {int }}=0.0301, R_{\text {sigma }}=0.0140\right)$ which were used in all calculations. The final $\mathrm{R}_{1}$ was $0.0306\left(\mathrm{I}>2 \sigma(\mathrm{I})\right.$ ), and $\mathrm{wR}_{2}$ was 0.0807 (all data). Flack parameter $=0.06(4)$.

Crystal data for compound $2(\mathrm{M}=410.45 \mathrm{~g} / \mathrm{mol})$ : monoclinic, space group $\mathrm{P} 2{ }_{1}$, $\mathrm{a}=$ 8.0642(2) $\AA, \mathrm{b}=10.6239(3) \AA, \mathrm{c}=11.9568(3) \AA, \beta=107.411(2)^{\circ}, \mathrm{V}=977.44(5) \AA^{3}, \mathrm{Z}=2$, $\mathrm{T}=100.00(10) \mathrm{K}, \mu(\mathrm{Cu} \mathrm{K} \alpha)=0.888 \mathrm{~mm}^{-1}, \mathrm{D}_{\text {calc }}=1.395 \mathrm{~g} / \mathrm{cm}^{3}, 9576$ reflections measured $\left(7.75^{\circ} \leq 2 \theta \leq 146.844^{\circ}\right), 3595$ unique $\left(R_{\text {int }}=0.0302, R_{\text {sigma }}=0.0220\right)$ which were used in all calculations. The final $\mathrm{R}_{1}$ was 0.0353 ( $\mathrm{I}>2 \sigma(\mathrm{I})$ ), and $\mathrm{wR}_{2}$ was 0.0946 (all data). Flack parameter $=0.09(8)$.

Crystal data for compound $3(\mathrm{M}=364.44 \mathrm{~g} / \mathrm{mol})$ : monoclinic, space group $\mathrm{P} 2{ }_{1}$, $\mathrm{a}=7.0067(2) \AA, \mathrm{b}=13.4001(4) \AA, c=9.7581(3) \AA, \beta=90.421(2)^{\circ}, \mathrm{V}=916.17(5) \AA^{3}, \mathrm{Z}=2$, $\mathrm{T}=293(2) \mathrm{K}, \mu(\mathrm{Cu} \mathrm{K} \alpha)=0.795 \mathrm{~mm}^{-1}, \mathrm{D}_{\text {calc }}=1.328 \mathrm{~g} / \mathrm{cm}^{3}, 8696$ reflections measured $\left(9.062^{\circ} \leq 2 \theta \leq 147.176^{\circ}\right), 3440$ unique $\left(R_{\text {int }}=0.0639, R_{\text {sigma }}=0.0435\right)$ which were used in all calculations. The final $R_{1}$ was 0.0355 (I $>2 \sigma(\mathrm{I})$ ), and $\mathrm{wR}_{2}$ was 0.0908 (all data). Flack parameter $=0.09(9)$.

Crystal data for compound $4(\mathrm{M}=378.41 \mathrm{~g} / \mathrm{mol})$ : orthorhombic, space group $\mathrm{P} 2{ }_{1} 2_{1} 2_{1}$, $\mathrm{a}=9.63490(10) \AA, \mathrm{b}=12.0407(2) \AA, \mathrm{c}=15.6703(2) \AA, \beta=90^{\circ}, \mathrm{V}=1817.93(4) \AA^{3}, \mathrm{Z}=4$, $\mathrm{T}=100.00(10) \mathrm{K}, \mu(\mathrm{Cu} \mathrm{K} \alpha)=0.868 \mathrm{~mm}^{-1}, \mathrm{D}_{\text {calc }}=1.383 \mathrm{~g} / \mathrm{cm}^{3}, 14,343$ reflections measured $\left(9.262^{\circ} \leq 2 \theta \leq 146.826^{\circ}\right), 3607$ unique $\left(R_{\text {int }}=0.0285, R_{\text {sigma }}=0.0201\right)$ which were used in all calculations. The final $R_{1}$ was $0.0284\left(\mathrm{I}>2 \sigma(\mathrm{I})\right.$ ), and $\mathrm{wR}_{2}$ was 0.0746 (all data). Flack parameter $=-0.05(6)$.

Crystal data for compound $5(\mathrm{M}=457.51 \mathrm{~g} / \mathrm{mol})$ : monoclinic, space group I2, $\mathrm{a}=7.84600(10) \AA, \mathrm{b}=12.85380(10) \AA, \mathrm{c}=22.0124(2) \AA, \beta=95.8390(10)^{\circ}, \mathrm{V}=2208.45(4) \AA^{3}$, $\mathrm{Z}=4, \mathrm{~T}=100.00(10) \mathrm{K}, \mu(\mathrm{Cu} \mathrm{K} \alpha)=0.828 \mathrm{~mm}^{-1}, \mathrm{D}_{\text {calc }}=1.376 \mathrm{~g} / \mathrm{cm}^{3}, 20,973$ reflections measured $\left(7.976^{\circ} \leq 2 \theta \leq 147.044^{\circ}\right), 4407$ unique $\left(R_{\text {int }}=0.0497, R_{\text {sigma }}=0.0283\right)$ which were used in all calculations. The final $\mathrm{R}_{1}$ was $0.0334\left(\mathrm{I}>2 \sigma(\mathrm{I})\right.$ ), and $\mathrm{wR}_{2}$ was 0.0884 (all data). Flack parameter $=0.05(7)$.

Crystal data for compound $6(\mathrm{M}=466.47 \mathrm{~g} / \mathrm{mol})$ : orthorhombic, space group $\mathrm{P} 2{ }_{1} 2_{1} 2_{1}$, $\mathrm{a}=13.8037(6) \AA, \mathrm{b}=12.1850(6) \AA, \mathrm{c}=12.0498(5) \AA, \beta=90^{\circ}, \mathrm{V}=2026.75(16) \AA^{3}, \mathrm{Z}=4$, $\mathrm{T}=113(20) \mathrm{K}, \mu(\mathrm{Cu} \mathrm{K} \alpha)=1.079 \mathrm{~mm}^{-1}, \mathrm{D}_{\text {calc }}=1.529 \mathrm{~g} / \mathrm{cm}^{3}, 7421$ reflections measured $\left(7.336^{\circ} \leq 2 \theta \leq 147.508^{\circ}\right), 3904$ unique $\left(R_{\text {int }}=0.0401, R_{\text {sigma }}=0.0517\right)$ which were used in all calculations. The final $\mathrm{R}_{1}$ was $0.0503\left(\mathrm{I}>2 \sigma(\mathrm{I})\right.$ ), and $\mathrm{wR}_{2}$ was 0.1464 (all data). Flack parameter $=-0.04(9)$.

Crystal data for compound $7(\mathrm{M}=430.44 \mathrm{~g} / \mathrm{mol})$ : orthorhombic, space group P $2{ }_{1} 2_{1} 2_{1}$, $\mathrm{a}=6.94750(10) \AA, \mathrm{b}=9.86740(10) \AA, \mathrm{c}=28.8229(4) \AA, \beta=90^{\circ}, \mathrm{V}=1975.92(4) \AA^{3}, \mathrm{Z}=4$, $\mathrm{T}=100.00(10) \mathrm{K}, \mu(\mathrm{Cu} \mathrm{K} \alpha)=0.983 \mathrm{~mm}^{-1}, \mathrm{D}_{\text {calc }}=1.447 \mathrm{~g} / \mathrm{cm}^{3}, 22,539$ reflections measured $\left(6.132^{\circ} \leq 2 \theta \leq 147.044^{\circ}\right), 3946$ unique $\left(R_{\text {int }}=0.0695, R_{\text {sigma }}=0.0368\right)$ which were used in all calculations. The final $\mathrm{R}_{1}$ was $0.0372(\mathrm{I}>2 \sigma(\mathrm{I}))$, and $\mathrm{wR}_{2}$ was 0.1016 (all data). Flack parameter $=-0.12(9)$.

Crystal data for compound $8(\mathrm{M}=480.45 \mathrm{~g} / \mathrm{mol})$ : orthorhombic, space group $\mathrm{P} 2{ }_{1}{ }_{2} 2_{1}{ }_{1}$, $\mathrm{a}=7.02070(10) \AA, \mathrm{b}=13.3311(2) \AA, \mathrm{c}=22.4885(3) \AA, \beta=90^{\circ}, \mathrm{V}=2104.78(5) \AA^{3}, \mathrm{Z}=4$, 
$\mathrm{T}=100.01(10) \mathrm{K}, \mu(\mathrm{Cu} \mathrm{K} \alpha)=1.097 \mathrm{~mm}^{-1}, \mathrm{D}_{\text {calc }}=1.516 \mathrm{~g} / \mathrm{cm}^{3}, 20,217$ reflections measured $\left(7.71^{\circ} \leq 2 \theta \leq 147.848^{\circ}\right), 4187$ unique $\left(R_{\text {int }}=0.0429, R_{\text {sigma }}=0.0296\right)$ which were used in all calculations. The final $R_{1}$ was $0.0282\left(\mathrm{I}>2 \sigma(\mathrm{I})\right.$ ), and $\mathrm{wR}_{2}$ was 0.0734 (all data). Flack parameter $=-0.01(6)$.

Crystal data for compound $9(\mathrm{M}=410.41 \mathrm{~g} / \mathrm{mol})$ : monoclinic, space group C2, $\mathrm{a}=17.7027(6) \AA, \mathrm{b}=8.4150(3) \AA, \mathrm{c}=12.3274(3) \AA, \beta=99.070(3)^{\circ}, \mathrm{V}=1813.43(10) \AA^{3}$, $\mathrm{Z}=4, \mathrm{~T}=100.00(10) \mathrm{K}, \mu(\mathrm{Cu} \mathrm{K} \alpha)=1.004 \mathrm{~mm}^{-1}, \mathrm{D}_{\text {calc }}=1.503 \mathrm{~g} / \mathrm{cm}^{3}, 16,975$ reflections measured $\left(7.262^{\circ} \leq 2 \theta \leq 147.362^{\circ}\right), 3635$ unique $\left(R_{\text {int }}=0.0514, R_{\text {sigma }}=0.0313\right)$ which were used in all calculations. The final $\mathrm{R}_{1}$ was $0.0388\left(\mathrm{I}>2 \sigma(\mathrm{I})\right.$ ), and $\mathrm{wR}_{2}$ was 0.1080 (all data). Flack parameter $=0.10(9)$.

Crystal data for compound $10(\mathrm{M}=428.42 \mathrm{~g} / \mathrm{mol})$ : orthorhombic, space group $\mathrm{P} 2{ }_{1}{ }_{2} 2_{1}$, $\mathrm{a}=7.2511(2) \AA, \mathrm{b}=10.6856(3) \AA, \mathrm{c}=24.0611(9) \AA, \beta=90^{\circ}, \mathrm{V}=1864.31(10) \AA^{3}, \mathrm{Z}=4$, $\mathrm{T}=100.00(10) \mathrm{K}, \mu(\mathrm{Cu} \mathrm{K} \alpha)=1.042 \mathrm{~mm}^{-1}, \mathrm{D}_{\text {calc }}=1.526 \mathrm{~g} / \mathrm{cm}^{3}, 17,396$ reflections measured $\left(7.348^{\circ} \leq 2 \theta \leq 147.984^{\circ}\right), 3693$ unique $\left(R_{\text {int }}=0.0511, R_{\text {sigma }}=0.0405\right)$ which were used in all calculations. The final $\mathrm{R}_{1}$ was $0.0375\left(\mathrm{I}>2 \sigma(\mathrm{I})\right.$ ), and $\mathrm{wR}_{2}$ was 0.0896 (all data). Flack parameter $=0.07(10)$.

\subsection{Cell Proliferation Assay}

HL-60 and K562 cells were cultured in 96-well plates and incubated at $37{ }^{\circ} \mathrm{C}, 5 \% \mathrm{CO}_{2}$ incubator. After incubation for $24 \mathrm{~h}$, the cell supernatants were discarded and supplemented with cell culture medium containing compounds at different concentrations. At $48 \mathrm{~h}$ after incubation, the cell supernatants in each well were removed and replaced with $100 \mu \mathrm{L}$ culture medium containing $10 \mu \mathrm{L}$ of cell counting kit-8 (Sigma-Aldrich, St. Louis, $\mathrm{MO}, \mathrm{USA}$ ), followed by incubation at $37^{\circ} \mathrm{C}, 5 \% \mathrm{CO}_{2}$ for $2 \mathrm{~h}$. The absorbance at $450 \mathrm{~nm}$ of the cells was measured using a Plate Reader. Cell proliferation was calculated according to the $\mathrm{OD}_{450}$ value in cells that were treated with or without compounds.

\section{Conclusions}

In summary, a further phytochemical study on the roots of the medicinal plant Eurycoma longifolia resulted in the isolation and characterization of 14 highly oxygenated $\mathrm{C}_{20}$ quassinoids, including 10 new ones (longifolactones G-P, 1-10). Structurally, compound $\mathbf{1}$ is the second member of a rare class of quassinoids featuring an unusual 2,5dioxatricyclo[5.2.2.0 $0^{4,8}$ undecane ring system. Compound 4 possesses a 14,15-epoxy functionality that is unprecedented in quassinoids, and compound 7 features an unusual $\alpha$-oriented hydroxyl group at C-14. In addition, compounds 5, 12, 13, and 14 showed potent anti-proliferation activities on two human leukemia cell lines, K562 and HL-60.

Supplementary Materials: The following are available online, Detailed UV, IR, HR-ESI-MS, and NMR spectra of compounds 1-14, as well as crystallographic data of compounds 1-10 are available as Supplementary Materials.

Author Contributions: W.-Q.Y. and W.T. performed the isolation, purification, structure determination, and written the manuscript. X.-J.H. performed the structural identification of the compounds. J.-G.S. conducted the single crystal X-ray diffraction experiments. Y.-Y.L. worked in biological experiments. Y.X. and C.-L.F. performed the extraction, isolation and structural identification of the compounds. Y.W., Z.-L.W., and W.-C.Y. designed the whole experiments and revised the paper. All authors have read and agreed to the published version of the manuscript.

Funding: This work was financially supported by the National Key R\&D Program of China (2018YFC1706200 and 2017YFC1703800), the National Natural Science Foundation of China (81803379, 82003610, and 82104539), the Local Innovative and Research Teams Project of Guangdong Pearl River Talents Program (2017BT01Y036), and the Key-Area Research and Development Program of Guangdong Province (2020B1111110004).

Institutional Review Board Statement: Not applicable.

Informed Consent Statement: Not applicable. 
Data Availability Statement: All data supporting this study is available in the manuscript and the Supplementary Materials.

Conflicts of Interest: The authors declare no conflict of interest.

Sample Availability: Samples of the compounds 1-14 are available from the authors.

\section{References}

1. Guo, Z.; Vangapandu, S.; Sindelar, R.W.; Walker, L.A.; Sindelar, R.D. Biologically active quassinoids and their chemistry: Potential leads for drug design. Curr. Med. Chem. 2005, 12, 173-190. [CrossRef] [PubMed]

2. Duan, Z.K.; Zhang, Z.J.; Dong, S.H.; Wang, Y.X.; Song, S.J.; Huang, X.X. Quassinoids: Phytochemistry and antitumor prospect. Phytochemistry 2021, 187, 112769. [CrossRef] [PubMed]

3. Zhao, W.Y.; Song, X.Y.; Zhao, L.; Zou, C.X.; Zhou, W.Y.; Lin, B.; Yao, G.D.; Huang, X.X.; Song, S.J. Quassinoids from Picrasma quassioides and their neuroprotective effects. J. Nat. Prod. 2019, 82, 714-723. [CrossRef]

4. Polonsky, J. Quassinoid bitter principles. Fortschr. Chem. Org. Naturst. 1973, 30, 101-150. [PubMed]

5. Polonsky, J. Quassinoid bitter principles II. Prog. Chem. Org. Nat. Prod. 1985, 47, 221-264. [CrossRef]

6. Ravindar, K.; Caron, P.Y.; Deslongchamps, P. Anionic polycyclization entry to tricycles related to quassinoids and terpenoids: A stereocontrolled total synthesis of (+)-cassaine. J. Org. Chem. 2014, 79, 7979-7999. [CrossRef]

7. Condakes, M.L.; Rosen, R.Z.; Harwood, S.J.; Maimone, T.J. A copper-catalyzed double coupling enables a 3-step synthesis of the quassinoid core architecture. Chem. Sci. 2019, 10, 768-772. [CrossRef]

8. Bhat, R.; Karim, A.A. Tongkat Ali (Eurycoma longifolia Jack): A review on its ethnobotany and pharmacological importance. Fitoterapia 2010, 81, 669-679. [CrossRef] [PubMed]

9. Nurhanan, M.Y.; Hawariah, L.P.A.; Ilham, A.M.I.; Shukri, M.A.M. Cytotoxic effects of the roots extracts of Eurycoma longifolia. Phytother. Res. 2005, 19, 994-996. [CrossRef]

10. Rehman, S.U.; Choe, K.; Yoo, H.H. Review on a traditional herbal medicine, Eurycoma longifolia Jack (Tongkat Ali): Its traditional uses, chemistry, evidence-based pharmacology and toxicology. Molecules 2016, 21, 331. [CrossRef]

11. Wong, P.F.; Cheong, W.F.; Shu, M.H.; The, C.H.; Chan, K.L.; AbuBakar, S. Eurycomanone suppresses expression of lung cancer tumor markers, prohibitin, annexin 1 and endoplasmic reticulum protein 28. Phytomedicine 2012, 19, 138-144. [CrossRef] [PubMed]

12. Tung, N.H.; Uto, T.; Hai, N.T.; Li, G.; Shoyama, Y. Quassinoids from the roots of Eurycoma longifolia and their antiproliferative activity on human cancer cell lines. Pharmacogn. Mag. 2017, 13, 459-462.

13. Hajjouli, S.; Chateauvieux, S.; Teiten, M.H.; Orlikova, B.; Schumacher, M.; Dicato, M.; Choo, C.Y.; Diederich, M. Eurycomanone and eurycomanol from Eurycoma longifolia Jack as regulators of signaling pathways involved in proliferation, cell death and inflammation. Molecules 2014, 19, 14649-14666. [CrossRef] [PubMed]

14. Yang, W.Q.; Shao, X.H.; Deng, F.; Hu, L.J.; Xiong, Y.; Huang, X.J.; Fan, C.L.; Jiang, R.W.; Ye, W.C.; Wang, Y. Unprecedented quassinoids from Eurycoma longifolia: Biogenetic evidence and antifeedant effects. J. Nat. Prod. 2020, 83, 1674-1683. [CrossRef]

15. Mitchell, R.E.; Stocklin, W.; Stefanovic, M.; Geissman, T.A. Chaparrolide and castelanolide, new bitter principles from Castela nicholsoni. Phytochemistry 1971, 10, 411-417. [CrossRef]

16. Polonsky, J.; Baskevitch, Z.; Gottlieb, H.E.; Hagaman, E.W.; Wenkert, E. Carbon-13 nuclear magnetic resonance spectral analysis of quassinoid bitter principles. J. Org. Chem. 1975, 40, 2499-2504. [CrossRef]

17. Chan, K.L.; Lee, S.P.; Sam, T.W.; Tan, S.C.; Noguchi, H.; Sankawa, U. 13ß,18-dihydroeurycomanol, a quassinoid from Eurycoma longifolia. Phytochemistry 1991, 30, 3138-3141.

18. Morita, H.; Kishi, E.; Takeya, K.; Itokawa, H.; Tanaka, O. New quassinoids from the roots of Eurycoma longifolia. Chem. Lett. 1990, 19, 749-752. [CrossRef]

19. Morita, H.; Kishi, E.; Takeya, K.; Itokawa, H.; Iitaka, Y. Highly oxygenated quassinoids from Eurycoma longifolia. Phytochemistry 1993, 33, 691-696. [CrossRef]

20. Itokawa, H.; Kishi, E.; Morita, H.; Takeya, K. Cytotoxic quassinoids and tirucallane-type triterpenes from the woods of Eurycoma longifolia. Chem. Pharm. Bull. 1992, 40, 1053-1055. [CrossRef]

21. Meng, D.L.; Li, X.; Han, L.F.; Zhang, L.L.; An, W.W.; Li, X. Four new quassinoids from the roots of Eurycoma longifolia. Fitoterapia 2014, 82, 105-110. [CrossRef] [PubMed]

22. Miyake, K.; Tezuka, Y.; Awale, S.; Li, F.; Kadota, S. Quassinoids from Eurycoma longifolia. J. Nat. Prod. 2009, 72, 2135-2140. [CrossRef] [PubMed]

23. Lübben, J.; Wandtke, C.M.; Hübschle, C.B.; Ruf, M.; Sheldrich, G.M.; Dittrich, B. Aspherical scattering factors for SHELXL-model, implementation and application. Acta Crystallogr. A 2019, 75, 50-62. [CrossRef] [PubMed] 